\title{
International Law and the New African States
}

bY FELIX CHUKS OKOYE, LL.B., PH.D.

of Gray's Inn, Barrister-at-Law

New nations have proliferated since the end of the second world war. Their participation in the international legal order, together with unprecedented developments in international organisations and technology have greatly circumscribed the frontiers of traditional international law and have focused attention on the evolution of a contemporary international law.

The newly emerged nations generate especial international interest as they have different legal, social, cultural, ethical and religious backgrounds from the established nations predominantly of western civilisation. The process by which they achieved independence, for instance, has fermented new problems in the laws of nationality and state succession. This book examines the process of this evolution primarily by reference to the role and attitudes of the African states towards certain aspects of traditional law and international organisations.

Part I discusses the evolution of the international personality of the African states. Part II deals with the relationship between African municipal law and international law. Part III contains a detailed account and legal analysis of the problems of state succession raised by decolonisation. Part IV covers the Organisation of African Unity and other developments in multinational co-operation, such as the African approach to the concepts of regionalism in international law. Part $V$ deals with aspects of state responsibility, international co-operation, sources of law and the peaceful settlement of international disputes and contains an assessment of the impact which the African states have made on international law.

\section{Sweet \& Maxwell}

Mail orders to: North Way, Andover, Hants, England. 